\title{
Availability of Educational Resources and Student Academic Performances in South Africa
}

\author{
Kutu Augustine Adebayo*, Nzimande Ntokozo, Ngema Zukiswa Grace
}

Macroeconomics Research Unit (MRU), School of Accounting, Economics \& Finance, University of KwaZulu-Natal, South Africa

Received May 4, 2020 ; Revised June 15, 2020; Accepted July 7, 2020

Copyright $\bigcirc 2020$ by authors, all rights reserved. Authors agree that this article remains permanently open access under the terms of the Creative Commons Attribution License 4.0 International License

\begin{abstract}
The education system in South Africa is characterised by unequal education structures between the affluent and non-affluent schools, poor academic performance by learners and high drop-out rates. While educational expenditure has doubled over the years to support the non-affluent schools, educational outcomes have not followed suit. The affluent schools tend to perform at a much better rate on average, than non-affluent schools. Therefore, using the 2015 Trends in Mathematics and Science Study (TIMSS, 2015), this paper analysed the factors that impact on student performance within the non-affluent schools, and further examined the effect of availability of educational resources on student academic outcomes. The study finds that educational resources have a significant impact on student performances. However, the magnitude of the impact is minute as compared to other factors such as school management, accountability, and student self-determination. Therefore, the study concludes that educational resources in isolation are not necessarily the key tool for tackling the broader educational outcomes but rather it is a combination of many factors, which may lead to improved educational outcomes in South Africa.
\end{abstract}

Keywords Educational Resources, Student Academic Performances, Probit Model

JEL Classification: E61; E65

\section{Introduction}

There is a consensus among scholars and policymakers across the global that education is fundamental to economic growth and development (Hanushek, 2012 and Araya and Peters, 2010). As such, the South African government continues to make education a high priority by placing a large portion of the national and provincial budget allocation on education. To date, the government has managed to achieve close to $100 \%$ grade 1 enrollment rates each year (Posel, 2011). In addition, basic education is allocated one of the largest portions of the national budget. For the year 2018/19, the government allocated over R246 billion towards basic education, with an average annual growth rate of $7.1 \%$ predicated over the next three years. This expenditure, as per share of GDP, is comparable to countries such as Mexico and Brazil and slightly below countries in the Organisations for Economic Co-operation and Development (OECD). Since 1994, the country has seen a doubling of the education expenditure in the national budget.

The purpose of the budget is aimed at providing and ensuring adequate educational resources in schools. However, despite the government's commitment, the country's academic performance levels is at their lowest even when compared to other African and international countries (Sommer and Dumont, 2011). The educational system is characterised by poor student academic achievements, high dropout rates, and inequalities (Badat, 2010). When the educational system is broken down into the affluent and non-affluent schools categories, it is found that affluent schools which are likely to be more adequately resourced, generally perform at a much better rate on average than non-affluent schools which are likely to be less adequately resourced (Adams, 2010). Therefore, this paper aims to analyse the different factors that impact on student academic performance levels within the non-affluent and historically disadvantaged schools. It attempts to analyse the role educational resources has played on student academic performance, and revealed that the presence of educational resources increases the learner's probability to perform at international benchmarks.

The structure of this paper will be organized as follows. Section 2 is a brief overview of the historical academic performances in South Africa. Section 3 is a presentation of literature that have been written on the factors affecting educational attainment and quality. Section 4 provides an 
overview to demonstrate the importance of quality education on the economy, then section 5 presents the research methodology and descriptive statistics of the data with interpretation of results from the model, and section 6 provides the results and policy recommendation.

\section{Historical Performance of South African Learners}

A conclusion from the various local and international assessments is that South African learners find it difficult to read, write, understand, and solve problems in language, mathematics and science (Ndlovu, 2011, Mouton et al., 2012 and Spaull, 2013). From the local perspective, the National Senior Certificate (NSC) may be used as an approximate measure of the academic performance in South Africa (see Botha, 2012). Figure 1 provides the average number of students who achieved the minimum results required for University enrollment. In South Africa, a learner has to achieve a minimum of $40 \%$ in three academic subjects including one official home language, and a minimum of $30 \%$ in three other academic subjects in order to pass the NSC examinations (Wedekind, 2013). However, in order to enroll in University, a learner must achieve a minimum of $30 \%$ in a language of learning and more than 50\% in four other academic subjects (Moloi et al., 2010 and Spaull, 2013). Figure 1 shows the minimum pass rates and requirement for University education. Over the period between 2010 and 2017, the national average of bachelor passes was $26.76 \%$. This means that more than $70 \%$ of students in South Africa who wrote the NSC examinations did not achieve the minimum result levels required for University entrance (Department of Basic Education, 2019).

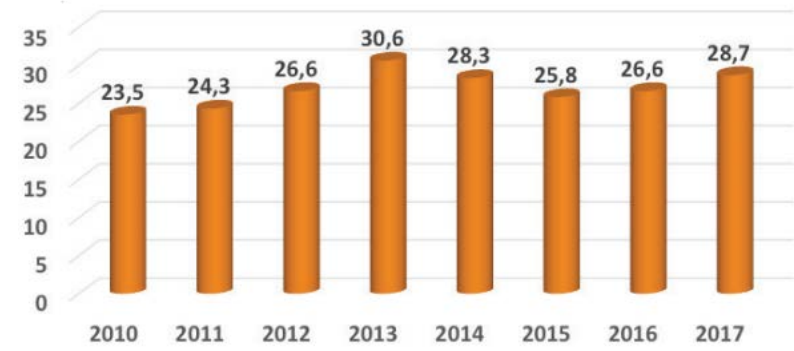

Source: Department of Education, 2019

Figure 1. Minimum Pass Rate and Requirements for University Entrance

The academic performance of the learners in the lower grades is also a concern, as grade repetition is prevalent, especially in grade 10 and 11 . Figure 2 shows that for the period between 2009 and 2016, the minimum and maximum percentage of grade repetition for grade 10 was $17.1 \%$ (2009) and 24.5\% (2013), respectively. In grade 11 with an average age of 16 and 17 years, the minimum and maximum percentage of grade repetition was 15.6\% (2012) and 21.1\% (2013), respectively (Department of Basic Education, 2019). These have revealed the poor academic performance of students in South Africa.

According to Mlachila and Moeletsi (2019), the low educational outcomes at the grade 12 level are because of learning shortfalls at the primary school level and lack of resources of which high schools are unable to control. Thus, the transition from primary to secondary level becomes challenging for learners. The same is true at the tertiary level, as over a quarter of learners drop out within the first year of the academic year. In 2015, about half of South Africans aged between 25 and 35 had not completed secondary education (Mlachila and Moeletsi, 2019).

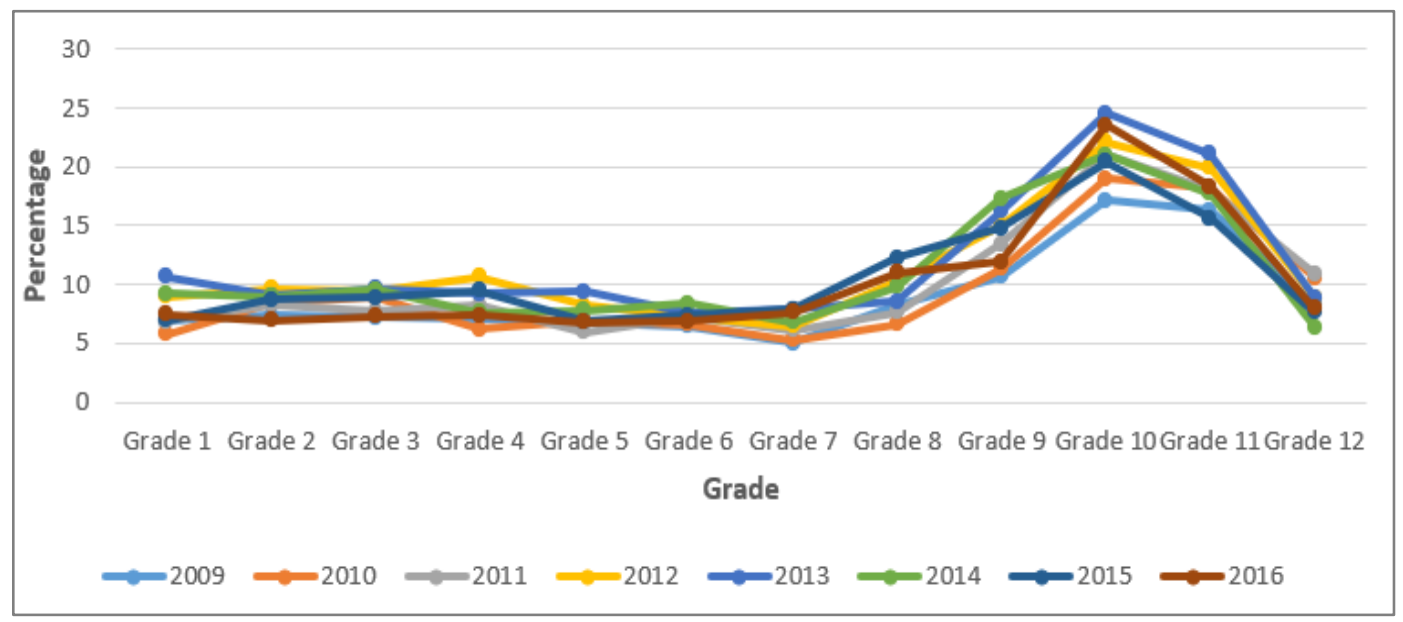

Source: Author's computation using data from Department of Education, 2019

Figure 2. Grade Repetition for Period 2009 - 2016 from Grade 1 - 12 


\section{Factors Affecting Educational Attainment and Quality}

Literature has found that the causes of South Africa's poor academic performance are vast and multidimensional. Key common factors include low socio-economic status, lack of resources, and poor school management. Soudien (2016) argues that the bequest of the apartheid regime continues to have a strong determinant and influential factor in the performance of learners in schools. A journal written by the US Embassy (2009) extends on this by stating that legacy of apartheid resulted in resource constraints. This is highly evident when comparing independent or private school's outcomes against public schools' outcomes. The difference in the outcomes between the private and public schools is an indication that socio-economics, and resource constraints play a vital role in the academic achievement of students.

Fan (2012) provides an overview of the causes of poor student performance of grade 12/matric learners (students with average age of 17 and 18 years). The information, gathered through interviews, on the causes of poor student performance showed the main factors included lack of resources, student discipline, poor morale, issues concerning the implementation of policies, and inadequate parental involvement in the student's education. On the other hand, Njora Hungi (2011) utilized the multivariate analyses procedure to study learner and school-level factors that contribute to variations in reading and mathematics achievement among grade 6 pupils in 15 African school systems (Botswana, Kenya, Lesotho, Malawi, Mauritius, Mozambique, Namibia, the Seychelles, South Africa, Swaziland, Tanzania, Uganda, Zambia, Zanzibar, and Zimbabwe). The study found that, at the student level, repetition of a grade, socio-economic background, student age, and student gender are the most important factors affecting the variations in pupil achievement in these school systems. At the school level, the school's resources and the school's location were identified as the important common factors affecting pupil achievement. The study found that South Africa and Zimbabwe had the largest variation (especially in reading), and that socioeconomic status of pupils was responsible for the variation in student achievement.
Spaull (2013) investigates the relationship between educational outcomes and Socio-Economic Status (SES), pupil and teacher characteristics and school resources and processes using the Southern and Eastern Africa Consortium for Monitoring Educational Quality (SACMEQ) data set. The results showed that poor schools were not able to overcome socioeconomic disadvantages about academic achievement, whereas with the affluence schools, SES had an insignificant impact. This finding is in line with Mlachila and Moeletsi (2019) who found that insufficient subject knowledge of some teachers, oppressive history, race, language, geographic location, and SES affect students educational attainment.

\section{Overview of the Importance of Quality Education on the Economy}

The level of educational achievement in South Africa can be used as a strong predictor of the differences in employment and unemployment rates across the country. Although the overall unemployment rate in South Africa is substantially high, tertiary graduates' employment rates are high. According to Brain (2015), the OECD 2015 insight revealed that $81 \%$ of tertiary graduates obtained employment in 2015, comparable with the OECD average of $84 \%$. On the other hand, South Africans with less than primary school completed had the highest unemployment rates. The variations in the level of education of South African workers can explain a great part of variations in employment prospects, when controlled in the form of a population group, household and urban residences.

Branson et al (2013) revealed the relationship between the level of education completed and monthly earnings for South Africans. The authors show that people with higher levels of education are hugely rewarded in the labour market, with regard to earnings; they also show that an individual's prospects of employment is improved by tertiary education. Moses et al (2017) also focused their research on understanding the role of education on social mobility for the poor in South African. They concluded that educational attainment is a significant forecaster of the labour market outcomes as shown in figure 3 below. 


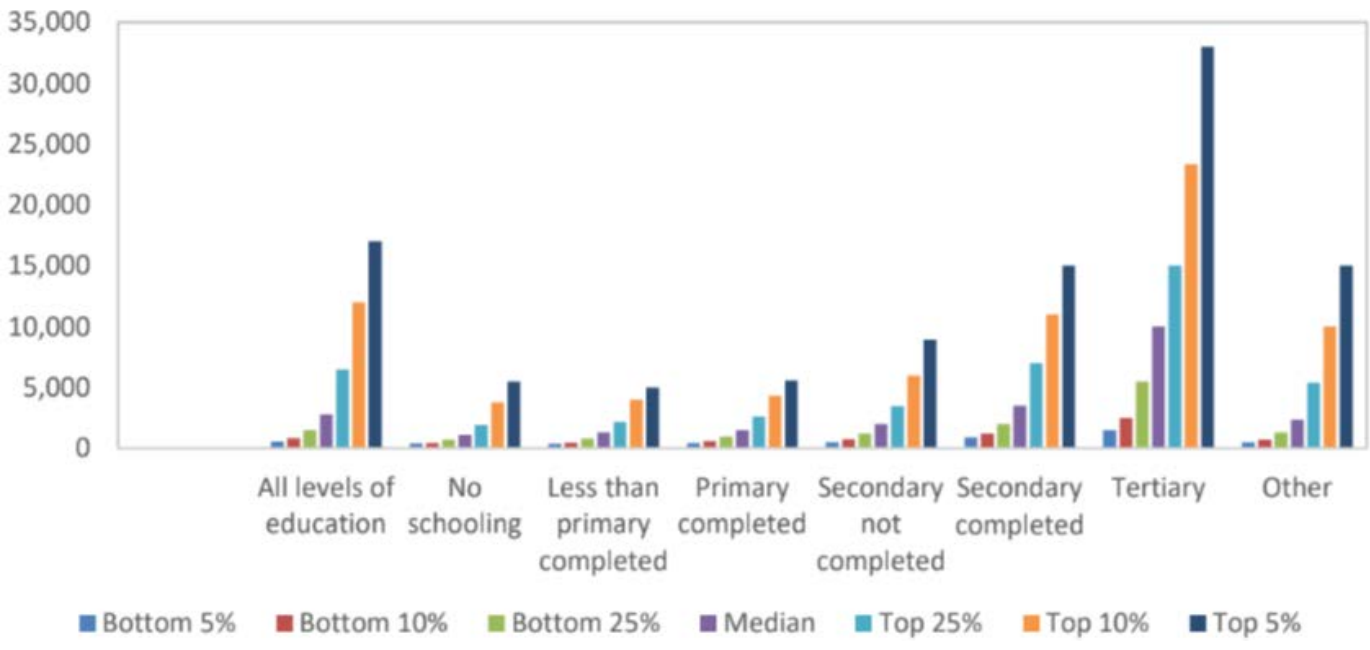

Source: Stats SA, 2010

Figure 3. Distribution of Monthly Earnings by Education Level in 2010

Figure 3 provides illustration for the distribution of income earnings per educational levels. The figure draws a reality in South Africa that people who have tertiary education had the highest income earnings and are in the top $5 \%$ in terms of SES. In addition, people who are in the range of educational level of "no schooling" to "secondary school" had the least earnings. Hence, education plays an important role on the economy.

\section{Research Methodology}

\subsection{Presentation of the Data and Data Sources}

This paper uses the Trend in Mathematical and Science study TIMSS (2015) dataset. The TIMSS dataset is an international assessment of mathematics and science at grade 5 and 9 . The dataset provides extensive background information about the learners who wrote the assessment, their home backgrounds, support systems, schoolteachers, and school environment.

\subsection{Description of the Dataset}

TIMSS is updated every four years since 1995. Although the latest 2019 version has been released, it is however not yet available for download, hence, the use of 2015 dataset for this study. The TIMSS 2015 South African data contains about 11,969 unique students. About 45 countries participated at the grade $8 / 9$ level. The data revealed that 8 341 (69.69\%) students achieved mathematical scores which were below the international mathematics Benchmark, and only 95 (0.7937\%) students reached the advanced international benchmark. In addition, the data also shows that a total of 3533 (29.52\%) students achieved mathematical scores which were between the intermediate international benchmark and the high international benchmark as shown in figure 4 below. 


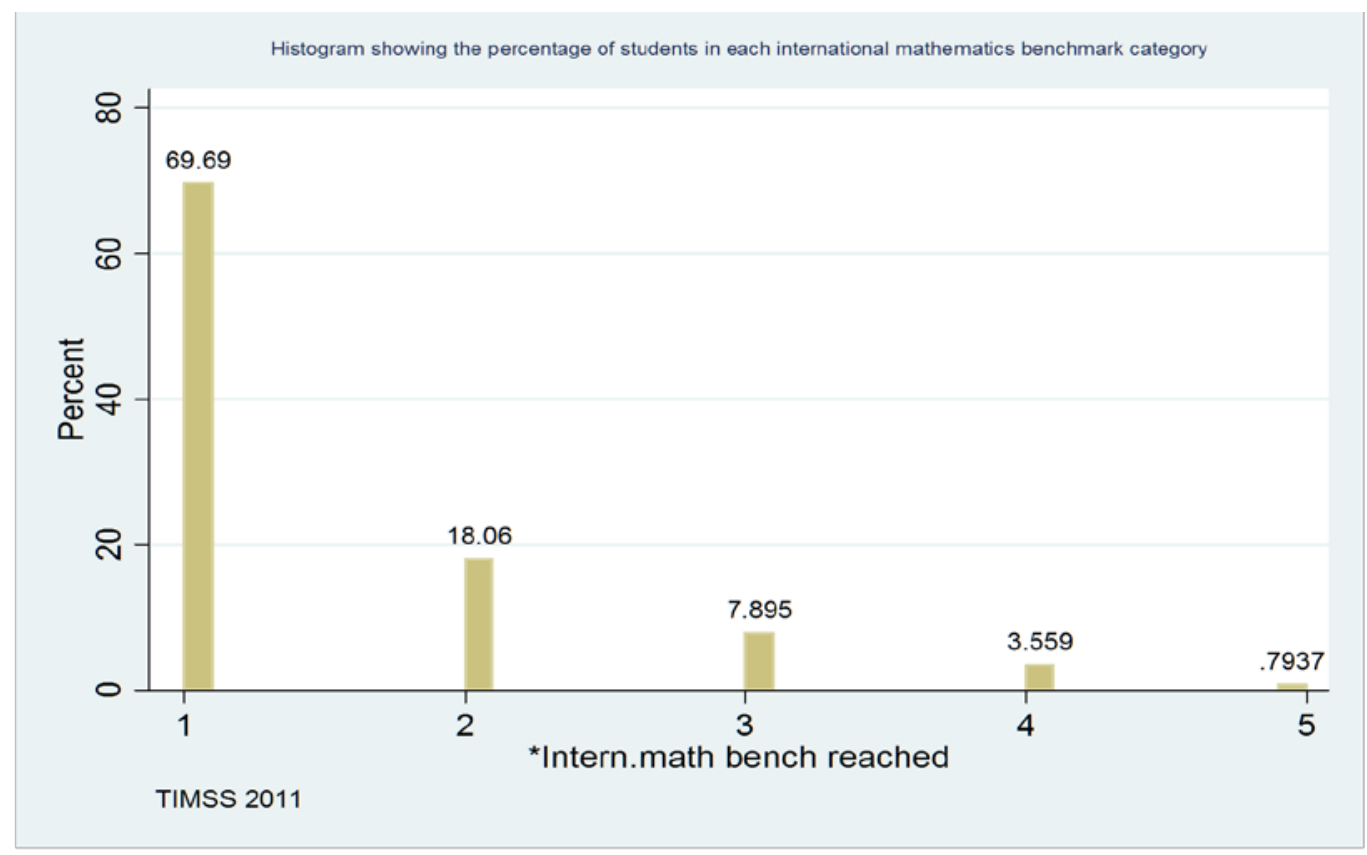

Source: TIMSS, 2011

Figure 4. International Mathematics Benchmark Score

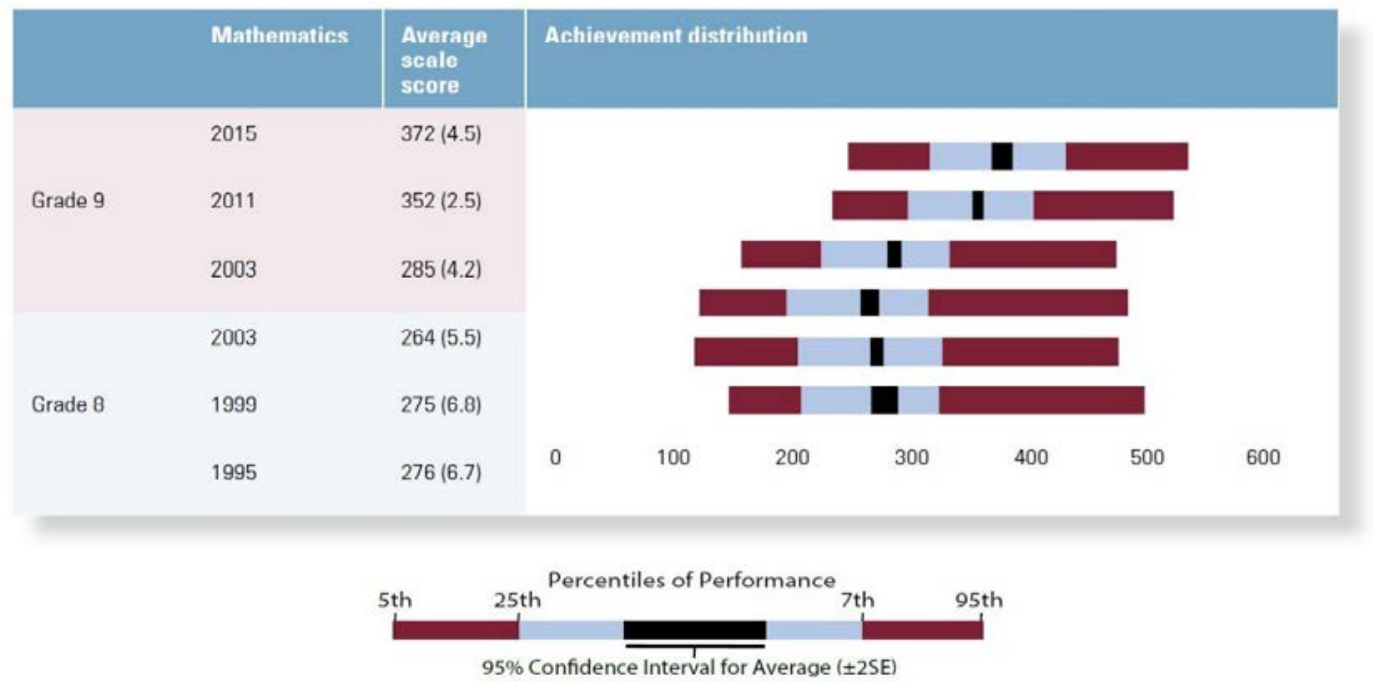

Source: TIMSS, 2015

Figure 5. Trends in Mathematics achievement in TIMSS 1995, 1999, 2003, 2011 and 2015

The data released for 2011 is similar to that of 2015 where Figure 5 shows that the average national mathematics score remained the same, statistically, over the 1995, 1999 and 2003 cycles.

In contrast, from 2003 to 2015 the average mathematics scores improved by 87 points. This change in the South African mathematics achievement scores means that the education system improved from a 'very low' (1995, 1999, 2003) to a 'low' (2011, 2015) national average.

Figure 6 below presents the academic performances of students between affluent and non-affluent schools. In South Africa, it can be observed that the majority of the formerly white schools are relatively more affluent and the historically disadvantaged schools are relatively non-affluent.

Non-affluent schools had the largest percentage (76.86\%) of students who achieved mathematical scores, which were below the low international benchmark. The affluent schools, on the other hand, had only $36.58 \%$ students who achieved a mathematical score, which was below the low international benchmark. The affluent schools had approximately $37.69 \%$ of students who achieved mathematical scores that were between the intermediate and high international benchmark while the non-affluent schools had only 5.715\%. 


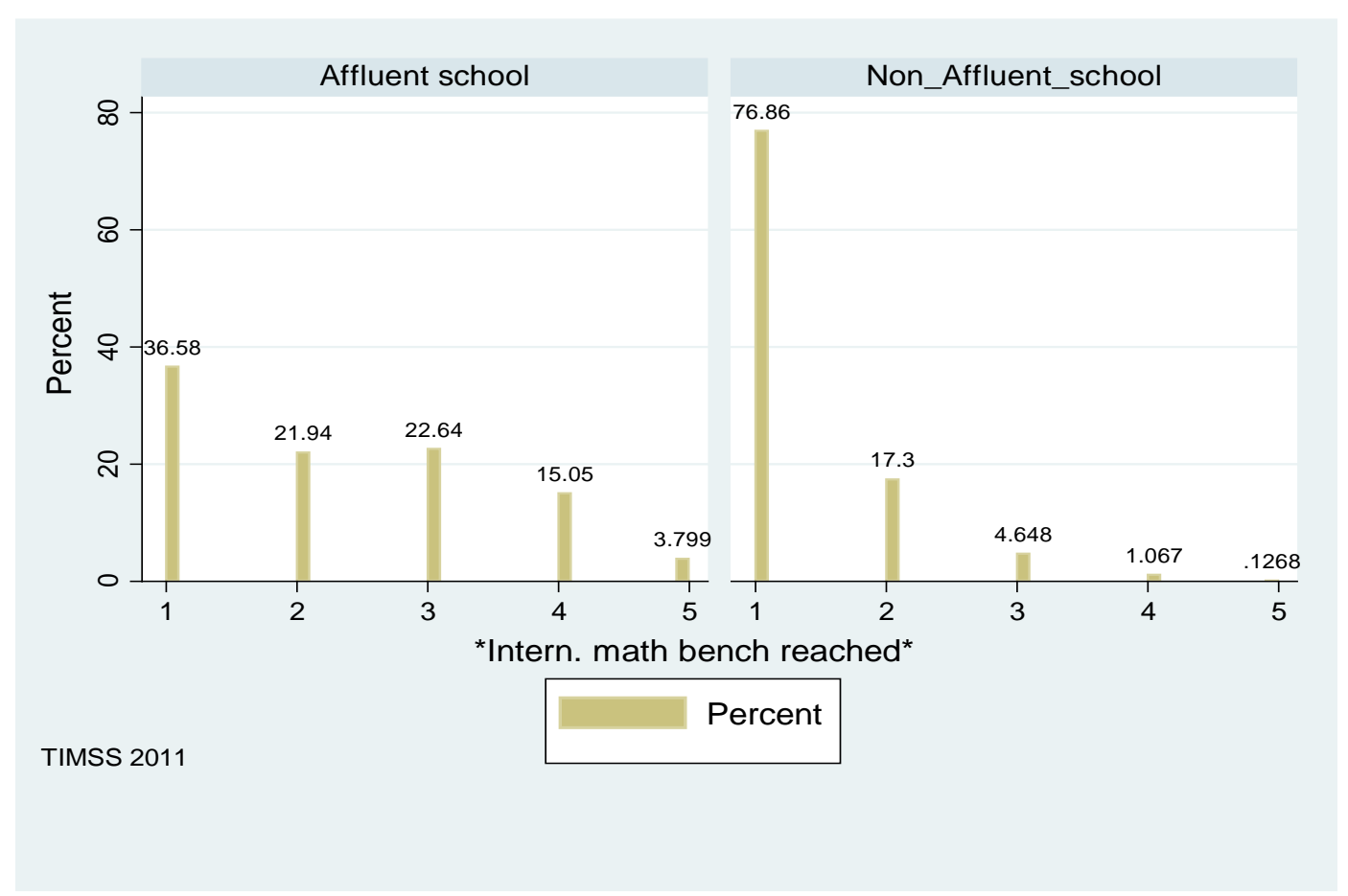

Source: TIMSS, 2011

Figure 6. Affluent Versus Non-affluent Schools in International Mathematics Benchmark

\subsection{Research Procedure and Techniques}

Following Spaull (2013), this paper assumed that schools with less than $25 \%$ disadvantaged students were classified as affluent schools. The variable, which indicates the percentage of disadvantaged students in the school, is already defined in the TIMSS dataset (see section 5.1.2). The idea behind this classification is to gain a better understanding of the conditions that are required for historically disadvantaged schools to function efficiently as hypothesized by Taylor et al. (2011).

Using probit regression model as given in the equation below:

$$
p\left[Y_{i}=1\left\{X_{i}, \ldots ., X_{k i j} ; \beta_{0 i}, \ldots . . \beta_{k}\right\}=\Phi\left(\beta_{0}+\sum_{K=1}^{K} \beta_{k} X_{k i}\right)\right.
$$

Where the function $\Phi(*)$, is the cumulative distribution function of the standard normal distribution. The equation explains that conditional on the regressors, the probability that the outcome variable is $\mathrm{Y}_{\mathrm{i}}=1$ (Advanced International Benchmark), is a function of a linear combination of the regressors. How much the mean outcome variable moves when one of the regressors changes, can be seen on the marginal equation as follows:

$$
\frac{\partial p\left[Y_{i}=1\left\{X_{1 i}, \ldots, X_{k i} ; \beta_{0}, \ldots \ldots \beta_{k}\right\}\right.}{\partial X_{k i}}=\beta_{k} \varnothing\left(\beta_{0}+\sum_{k=1}^{k} \beta_{k} X_{k i}\right)
$$

In other words, the marginal effects for the probit model (change in), and the quantity depends on the values of all the other regressors and the regression coefficient, where $\Phi$ is the standard normal probability density function.

\section{Results and Policy Recommendation}

\subsection{Results}

As shown in the regression model (see appendix), the school location category for the mathematics model had medium income area as significant variable, increasing the probability of achieving the advanced international benchmark category by a positive value if incomes are well distributed. This may change the pattern and lead to students showing increasing results in mathematics achievement. The insignificant value of other variables in the model have an implication of a declining achievement in mathematics by the students. The science model, on the other hand shows that students who are from schools that are located in the Urban, Suburban, medium size city, small town, and medium income areas are more likely to achieve the international advance benchmark. This shows that the students perform well in science than mathematics. The performance of students might not be unconnected to students' composition and background in which science module are combination of theory (memorization) and calculation while mathematics is purely calculation. Surprisingly, the high-income area is insignificant for both models. This is an unexpected outcome, as one would expect the variable to be a significant predictor of high achievement scores in both the science and mathematics models. However, it might be likely that the quality of schools has a greater impact on achievement in low-income countries than it does in high-income countries as revealed by Wiberg (2019). 
The results from the pupil characteristics on the science and mathematics models appear similar. The model reveals that "Age," "Girl", and "Language of Test often used at home" are statistically significant in both the mathematics and science subjects. The signs and marginal effects of the variables are also similar. In other words, the models reveal that Age has a negative relationship with the student performance; the older the student, the lower the probability of obtaining the advanced International Benchmark level in both Mathematics and Science. This is an expected result, as the older pupils might not be academically strong and may be repeating classes. The model shows that students who are Girls are much more likely to achieve advanced International Benchmark level in both Mathematics and Science, than Boys are. This might be due to the distractionary effects in boys and the influence among peers since parents pay more attention on their girl child than the boys. In addition, students that often speak the language of the test at home are much more likely to achieve advanced International Benchmark level in both Mathematics and Science, than those who do not. Indicating that Language is often a barrier for those who do not speak the language in which the test or examination is written.

The parents' level of education is statistically significant for both Mathematics and Science for Upper Secondary school. This means that students who have parents with upper secondary school education are likely to achieve advanced International Benchmark than those students whose parents only have Lower-Secondary school and less than Primary school. That is, the more educated the student's parents, the more likely they achieve the International Benchmark. In addition, the variable Number of books at home is statistically significant in both the mathematics and science models, positively increasing the likelihood of achieving advanced International Benchmark. Surprisingly, the variable given homework every-day and constant discussion of homework by teacher was not significant in both models. These might be that students failed to take homework serious, and may likely not have given desire attention to it. The pupil self-motivation variables, on the other hand, appear to be statistically significant and have one of the highest marginal effects, in other words the probability of those pupils who do not want to study mathematics or science decrease by 0.09 and 0.06 , respectively. Therefore, the interest of students often requires stimulation. The Socio-Economic Status (SES) indicator variable is statistically significant for both the mathematics and science models. Although, SES is significant and positively related to student's academic achievement, its impact on mathematics and science achievement levels appears to be mild, the marginal effect is 0.014 and 0.019 , respectively. Spaull (2013) also found similar results. He found that SES did not show a large significant impact on mathematics scores and the impact on reading was not too large as well.
In terms of school management, the variables "A lot of time spent keeping order," were statistically significant for both mathematics and science. The model showed an expected relationship, in other words we expect those schools where principals spends a lot of time keeping order to impact on the performance of the pupils. In terms of accountability, the following variables were statistically significant; "Observations by inspectors or other person external to evacuate mathematics and science teachers", and "Peer review used to evaluate mathematics teachers". The following results were also observed, "Adequacy of heating, cooling and lighting systems" were significant for mathematics. "Adequacy of in-structural space" had a negative sign and was observed to be statistically significant for both mathematics and science. Adequacy of teachers with a specialization in mathematics showed a significant relationship.

"No difficulty in filling teaching vacancies for science" showed significant outcome and had a marginal effects of 0.017. "Incentives to recruit or retain teachers in science", showed significant positive effect and a marginal effect of 0.035. "Adequacy of library material relevant to science instruction was statistically significant and has a marginal effect of 0.044 . Adequacy for science equipment and material for science instruction and science laboratory were both statistically significant having a marginal effect of -0.045 and 0.020 .

Although the school resources variables showed varying outcomes, they were nonetheless found to be jointly significant; therefore, they play an important role in explaining the variability in student's mathematical scores. The full model had an $\mathrm{R}^{2}$ of 0.5439 for mathematics with 5102 observations and 0.4868 for science with 4600 observations. The regression model has shown mixed results in terms of the impact of school resources to student outcomes. This may largely due to variability in students' interest towards mathematics and science subjects. Other statistically significant variables included "School Building does not require repairs", "Adequate infrastructural material and supplies", "Enough basic nutrition for student", "Adequacy in infrastructural material”, "Adequacy of library material relevant to science instruction”, “Adequacy for science equipment and material for science instruction", and "science laboratory". All these factors contribute significantly to the possibility of students achieving better outcomes in their academic performances.

\subsection{Conclusion and Policy Recommendation}

This study analyzed the different factors that impact on student academic performance levels within the non-affluent and historically disadvantaged schools using probit regression model that has the advantages of predicted probability and incorporate non-linear effects using the 2015 Trends in Mathematics and Science Study 
(TIMSS, 2015). As revealed by the model results, most of the increase in educational spending in South Africa has been at increasing access and inputs, but quality has significantly lagged. This was revealed by those variables in the model that were insignificant. More resources have not led to improved student outcomes. Fundamentally, improved teacher training, improved school management, and greater teacher accountability are some of the possible measures that have the greatest potential to improve educational performance. Significantly improving the availability of textbooks and related learning materials is likely to positively impact learner performance. However, a large variety of input-based policies on their own are largely ineffective in increasing learning outcomes in the absence of harmonizing initiatives to improve accountability and education. Therefore, as a policy recommendation, it can be recommended that government should increase budget allocation towards resources to cater for textbooks, learning materials and training of teachers. While major source of educational funding should be from the government, students should learn to pay bills and manage debt using a learn-by-doing approach where student fees are paid by their parents. As part of recommendation for future research, it would be interesting to conduct the same analysis using a more robust modern method like Generalized Method of Moments (GMM), Autoregressive Distributed Lag (ARDL) and Dynamic Stochastic General Equilibrium (DSGE) model. These methods improve upon the traditional probit and logit model methods and are capable of including more variables without the risk of running out of degrees of freedom.

\section{Appendix}

Table: Probit regression results

\begin{tabular}{|c|c|c|c|c|}
\hline & $\begin{array}{c}\text { Advanced International } \\
\text { Benchmark } \\
\text { Mathematics } \\
\text { Full sample } \\
\end{array}$ & $\begin{array}{c}\text { Advanced International } \\
\text { Benchmark } \\
\text { Mathematics } \\
\text { Non-Affluent Schools } \\
\end{array}$ & $\begin{array}{c}\text { Advanced International } \\
\text { Benchmark } \\
\text { Science } \\
\text { Full sample } \\
\end{array}$ & $\begin{array}{c}\text { Advanced } \\
\text { International } \\
\text { Benchmark } \\
\text { Science } \\
\text { Non-Affluent Schools } \\
\end{array}$ \\
\hline \multicolumn{5}{|c|}{ School location } \\
\hline \multirow[t]{2}{*}{ Urban } & 0.089 & 0.022 & $0.480 * * *$ & $0.657^{* * *}$ \\
\hline & $(0.162)$ & $(0.214)$ & $(0.150)$ & (0.199) \\
\hline \multirow[t]{2}{*}{ Suburban } & 0.219 & $0.449 * *$ & $0.295^{*}$ & $0.459 * * *$ \\
\hline & $(0.167)$ & (0.193) & $(0.151)$ & $(0.170)$ \\
\hline \multirow[t]{2}{*}{ Medium Size City } & 0.201 & $0.565 * * *$ & $0.703^{* * *}$ & $0.845^{* * *}$ \\
\hline & $(0.157)$ & $(0.185)$ & $(0.147)$ & (0.169) \\
\hline \multirow[t]{2}{*}{ Small Town } & 0.033 & -0.008 & $0.247^{*}$ & $0.365^{* *}$ \\
\hline & $(0.160)$ & $(0.182)$ & $(0.146)$ & $(0.166)$ \\
\hline \multirow[t]{2}{*}{ High Income Area } & 0.030 & -0.703 & 0.137 & -0.785 \\
\hline & $(0.207)$ & $(0.530)$ & $(0.247)$ & $(0.485)$ \\
\hline \multirow[t]{2}{*}{$\begin{array}{c}\text { Medium Income } \\
\text { Area }\end{array}$} & $0.415^{* * *}$ & $0.331^{* * *}$ & $0.308^{* * *}$ & $0.347^{* * *}$ \\
\hline & $(0.044)$ & $(0.065)$ & $(0.054)$ & $(0.077)$ \\
\hline \multicolumn{5}{|c|}{ Pupil Characteristics } \\
\hline \multirow[t]{2}{*}{ Age } & $-0.312 * * *$ & $-0.257 * * *$ & $-0.195^{* * *}$ & $-0.160 * * *$ \\
\hline & $(0.034)$ & $(0.036)$ & (0.033) & $(0.036)$ \\
\hline \multirow[t]{2}{*}{ Girl } & $0.177 * * *$ & 0.073 & $0.215 * * *$ & $0.154^{* *}$ \\
\hline & $(0.062)$ & $(0.077)$ & $(0.058)$ & $(0.069)$ \\
\hline \multirow{2}{*}{$\begin{array}{c}\text { Language of test } \\
\text { often } \\
\text { used at home }\end{array}$} & $0.121^{*}$ & 0.073 & $0.327 * * *$ & $0.299 * * *$ \\
\hline & $(0.071)$ & (0.098) & (0.069) & (0.093) \\
\hline Parents & -0.075 & 0.026 & 0.054 & 0.140 \\
\hline $\begin{array}{l}\text { highest level of } \\
\text { Post-Secondary }\end{array}$ & (0.079) & $(0.100)$ & $(0.077)$ & $(0.098)$ \\
\hline
\end{tabular}




\begin{tabular}{|c|c|c|c|c|}
\hline & $\begin{array}{c}\text { Advanced International } \\
\text { Benchmark } \\
\text { Mathematics } \\
\text { Full sample } \\
\end{array}$ & $\begin{array}{c}\text { Advanced International } \\
\text { Benchmark } \\
\text { Mathematics } \\
\text { Non-Affluent Schools } \\
\end{array}$ & $\begin{array}{c}\text { Advanced International } \\
\text { Benchmark } \\
\text { Science } \\
\text { Full sample } \\
\end{array}$ & $\begin{array}{c}\text { Advanced } \\
\text { International } \\
\text { Benchmark } \\
\text { Science } \\
\text { Non-Affluent Schools } \\
\end{array}$ \\
\hline Parents & $-0.291 * * *$ & $-0.234 * *$ & $-0.033 * *$ & $0.066^{* *}$ \\
\hline $\begin{array}{l}\text { highest level of } \\
\text { education: } \\
\text { Upper_Secondary }\end{array}$ & $(0.078)$ & (0.099) & $(0.076)$ & $(0.095)$ \\
\hline Parents & -0.205 & -0.154 & -0.183 & -0.145 \\
\hline $\begin{array}{l}\text { highest level of } \\
\text { education: } \\
\text { Lower_Secondary }\end{array}$ & $(0.125)$ & $(0.146)$ & (0.133) & $(0.147)$ \\
\hline Parents & -0.214 & -0.070 & -0.014 & 0.013 \\
\hline $\begin{array}{l}\text { highest level of } \\
\text { education: Less } \\
\text { than Primary } \\
\text { School }\end{array}$ & $(0.192)$ & $(0.191)$ & (0.149) & $(0.157)$ \\
\hline $\begin{array}{c}\text { Number of books at } \\
\text { home }\end{array}$ & $\begin{array}{c}0.126^{* * *} \\
(0.028)\end{array}$ & $\begin{array}{c}0.021 \\
(0.037)\end{array}$ & $\begin{array}{c}0.081^{* * *} \\
(0.026)\end{array}$ & $\begin{array}{c}0.030 \\
(0.032)\end{array}$ \\
\hline $\begin{array}{l}\text { Very highly } \\
\text { Involved } \\
\text { parent }\end{array}$ & $\begin{array}{c}0.344 \\
(0.281)\end{array}$ & $\begin{array}{c}0.060 \\
(0.590)\end{array}$ & $\begin{array}{l}0.483 * \\
(0.279)\end{array}$ & \\
\hline $\begin{array}{l}\text { Student wishes to } \\
\text { study } \\
\text { maths }\end{array}$ & $\begin{array}{c}-0.768^{* * *} \\
(0.096)\end{array}$ & $\begin{array}{c}-0.821^{* * *} \\
(0.137)\end{array}$ & & \\
\hline $\begin{array}{l}\text { Student wishes to } \\
\text { study } \\
\text { science }\end{array}$ & & & $\begin{array}{c}-0.415^{* * *} \\
(0.097)\end{array}$ & $\begin{array}{c}-0.411^{* * *} \\
(0.131)\end{array}$ \\
\hline $\begin{array}{c}\text { Maths homework } \\
\text { given } \\
\text { everyday }\end{array}$ & $\begin{array}{l}-0.009 \\
(0.016)\end{array}$ & $\begin{array}{l}-0.003 \\
(0.023)\end{array}$ & & \\
\hline Science homework & & & 0.036 & $0.062 *$ \\
\hline given everyday & & & $(0.025)$ & $(0.033)$ \\
\hline Socio-economic & $0.116^{* * *}$ & $0.100 * * *$ & $0.127 * * *$ & $0.093 * * *$ \\
\hline Indicator & $(0.022)$ & $(0.025)$ & (0.019) & $(0.020)$ \\
\hline \multirow[b]{2}{*}{$\begin{array}{l}\text { Very satisfied } \\
\text { teachers }\end{array}$} & & Teacher characteristics & & \\
\hline & $\begin{array}{c}0.652 * * * \\
(0.173)\end{array}$ & $\begin{array}{c}0.820 * * * \\
(0.239)\end{array}$ & $\begin{array}{l}0.176 \\
(0.163)\end{array}$ & $\begin{array}{l}0.492 * \\
(0.265)\end{array}$ \\
\hline $\begin{array}{l}\text { Discuss maths } \\
\text { homework } \\
\text { everyday }\end{array}$ & $\begin{array}{l}-0.034 \\
(0.132)\end{array}$ & $\begin{array}{r}0.182 \\
(0.175)\end{array}$ & & \\
\hline
\end{tabular}




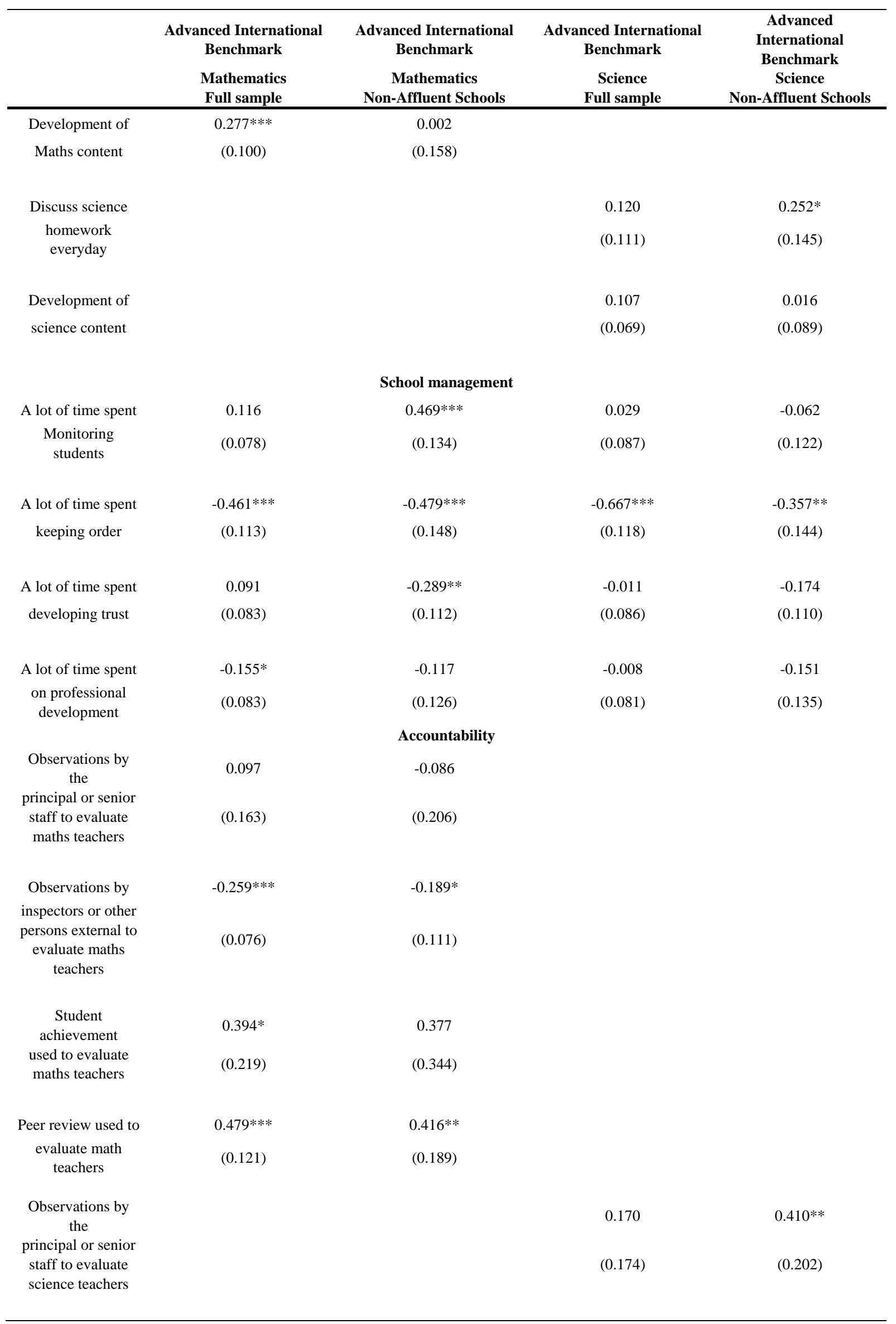




\begin{tabular}{|c|c|c|c|c|}
\hline & $\begin{array}{c}\text { Advanced International } \\
\text { Benchmark } \\
\text { Mathematics } \\
\text { Full sample } \\
\end{array}$ & $\begin{array}{c}\text { Advanced International } \\
\text { Benchmark } \\
\text { Mathematics } \\
\text { Non-Affluent Schools } \\
\end{array}$ & $\begin{array}{c}\text { Advanced International } \\
\text { Benchmark } \\
\text { Science } \\
\text { Full sample } \\
\end{array}$ & $\begin{array}{c}\text { Advanced } \\
\text { International } \\
\text { Benchmark } \\
\text { Science } \\
\text { Non-Affluent Schools } \\
\end{array}$ \\
\hline Observations by & & & $-0.130 *$ & $-0.170^{*}$ \\
\hline $\begin{array}{l}\text { inspectors or other } \\
\text { persons external to } \\
\text { evaluate science } \\
\text { teachers }\end{array}$ & & & $(0.071)$ & $(0.094)$ \\
\hline $\begin{array}{c}\text { Student } \\
\text { achievement }\end{array}$ & & & $0.882^{* * *}$ & $1.019^{* * *}$ \\
\hline $\begin{array}{l}\text { used to evaluate } \\
\text { science teachers }\end{array}$ & & & $(0.251)$ & $(0.381)$ \\
\hline Peer review used to & & & 0.170 & 0.017 \\
\hline $\begin{array}{l}\text { evaluate science } \\
\text { teachers }\end{array}$ & & & $(0.113)$ & $(0.132)$ \\
\hline \multicolumn{5}{|c|}{ Manner in which tests are structured } \\
\hline Test always require & $-0.207 * *$ & -0.148 & $-0.157^{*}$ & $-0.301^{* * *}$ \\
\hline $\begin{array}{l}\text { recall of } \\
\text { information }\end{array}$ & $(0.085)$ & $(0.124)$ & $(0.089)$ & $(0.108)$ \\
\hline Test always require & 0.072 & 0.006 & -0.036 & -0.030 \\
\hline $\begin{array}{l}\text { application of } \\
\text { procedure }\end{array}$ & $(0.091)$ & $(0.114)$ & $(0.091)$ & $(0.113)$ \\
\hline \multicolumn{5}{|c|}{ School resources } \\
\hline School & $0.346^{* * *}$ & 0.140 & $0.314^{* * *}$ & $0.412 * * *$ \\
\hline $\begin{array}{l}\text { Building does not } \\
\text { require repairs }\end{array}$ & $(0.074)$ & $(0.119)$ & $(0.087)$ & $(0.109)$ \\
\hline Classrooms are not & -0.053 & $0.445^{* * *}$ & -0.042 & 0.002 \\
\hline overcrowded & $(0.101)$ & $(0.160)$ & $(0.093)$ & $(0.167)$ \\
\hline $\begin{array}{c}\text { Adequate } \\
\text { in-structural }\end{array}$ & $0.401^{* * *}$ & $0.273^{*}$ & $0.556^{* * *}$ & $0.451^{* * *}$ \\
\hline $\begin{array}{l}\text { materials and } \\
\text { supplies }\end{array}$ & $(0.096)$ & (0.158) & (0.099) & $(0.134)$ \\
\hline \multirow[t]{2}{*}{$\begin{array}{c}\text { Enough basic } \\
\text { nutrition }\end{array}$} & $0.405^{* * *}$ & $0.348^{* * *}$ & $0.164^{*}$ & 0.149 \\
\hline & $(0.085)$ & $(0.110)$ & $(0.086)$ & $(0.103)$ \\
\hline Adequacy of & $0.712^{* * *}$ & $0.684^{* * *}$ & $0.587 * * *$ & 0.229 \\
\hline $\begin{array}{l}\text { instructional } \\
\text { material }\end{array}$ & $(0.108)$ & $(0.171)$ & (0.131)appe & $(0.172)$ \\
\hline \multirow[t]{2}{*}{$\begin{array}{l}\text { Adequacy of } \\
\text { supplies }\end{array}$} & $-0.191^{*}$ & -0.129 & 0.040 & 0.065 \\
\hline & $(0.106)$ & (0.144) & $(0.100)$ & $(0.134)$ \\
\hline $\begin{array}{l}\text { Adequacy of } \\
\text { school }\end{array}$ & 0.120 & -0.076 & 0.009 & 0.086 \\
\hline $\begin{array}{l}\text { buildings and } \\
\text { grounds }\end{array}$ & (0.099) & $(0.117)$ & $(0.097)$ & $(0.145)$ \\
\hline
\end{tabular}




\begin{tabular}{|c|c|c|c|c|}
\hline & $\begin{array}{c}\text { Advanced International } \\
\text { Benchmark } \\
\text { Mathematics } \\
\text { Full sample } \\
\end{array}$ & $\begin{array}{c}\text { Advanced International } \\
\text { Benchmark } \\
\text { Mathematics } \\
\text { Non-Affluent Schools } \\
\end{array}$ & $\begin{array}{c}\text { Advanced International } \\
\text { Benchmark } \\
\text { Science } \\
\text { Full sample } \\
\end{array}$ & $\begin{array}{c}\text { Advanced } \\
\text { International } \\
\text { Benchmark } \\
\text { Science } \\
\text { Non-Affluent Schools } \\
\end{array}$ \\
\hline $\begin{array}{l}\text { Adequacy of } \\
\text { heating }\end{array}$ & $-0.188^{* *}$ & $-0.213 *$ & 0.114 & -0.050 \\
\hline $\begin{array}{l}\text { cooling and } \\
\text { lighting systems }\end{array}$ & $(0.091)$ & $(0.129)$ & $(0.084)$ & $(0.127)$ \\
\hline Adequacy of & $-0.210 * *$ & 0.027 & $-0.241^{* *}$ & -0.082 \\
\hline Instructional space & $(0.096)$ & $(0.135)$ & $(0.118)$ & $(0.147)$ \\
\hline Adequacy of & 0.102 & 0.135 & 0.104 & $0.272 *$ \\
\hline $\begin{array}{l}\text { Technological } \\
\text { competent staff }\end{array}$ & $(0.101)$ & $(0.136)$ & $(0.111)$ & $(0.141)$ \\
\hline $\begin{array}{c}\text { Teacher } \\
\text { absenteeism }\end{array}$ & -0.236 & $-0.464 *$ & -0.135 & 0.005 \\
\hline not a problem & $(0.165)$ & $(0.239)$ & $(0.127)$ & $(0.159)$ \\
\hline Adequacy of & $-0.224^{* *}$ & $-0.329 * *$ & & \\
\hline $\begin{array}{l}\text { Teachers with a } \\
\text { specialization in } \\
\text { mathematics }\end{array}$ & $(0.105)$ & $(0.158)$ & & \\
\hline Adequacy & 0.034 & 0.186 & & \\
\hline $\begin{array}{l}\text { Of library materials } \\
\text { relevant to } \\
\text { mathematics } \\
\text { instruction }\end{array}$ & $(0.124)$ & $(0.212)$ & & \\
\hline \multicolumn{5}{|l|}{$\begin{array}{l}\text { Audio visual } \\
\text { resources } \\
\text { for mathematics } \\
\text { instruction }\end{array}$} \\
\hline \multicolumn{5}{|l|}{$\begin{array}{l}\text { Adequacy of } \\
\text { computers } \\
\text { for mathematics } \\
\text { instruction }\end{array}$} \\
\hline Adequacy of & -0.010 & 0.008 & & \\
\hline $\begin{array}{l}\text { Computer software } \\
\text { for mathematics } \\
\text { instruction }\end{array}$ & $(0.154)$ & $(0.257)$ & & \\
\hline $\begin{array}{l}\text { Not affected by } \\
\text { maths }\end{array}$ & $0.631^{* * *}$ & $0.973^{* * *}$ & & \\
\hline resource shortage & $(0.160)$ & $(0.271)$ & & \\
\hline $\begin{array}{l}\text { No difficulty in } \\
\text { filling }\end{array}$ & & & $-0.132 *$ & $-0.260 * *$ \\
\hline $\begin{array}{l}\text { teaching vacancies } \\
\text { for science }\end{array}$ & & & $(0.078)$ & $(0.105)$ \\
\hline $\begin{array}{l}\text { Incentives to } \\
\text { recruit or }\end{array}$ & & & $0.233^{*}$ & -0.006 \\
\hline $\begin{array}{l}\text { retain teachers in } \\
\text { science }\end{array}$ & & & $(0.122)$ & $(0.197)$ \\
\hline
\end{tabular}




\begin{tabular}{|c|c|c|c|c|}
\hline & $\begin{array}{c}\text { Advanced International } \\
\text { Benchmark } \\
\text { Mathematics } \\
\text { Full sample } \\
\end{array}$ & $\begin{array}{c}\text { Advanced International } \\
\text { Benchmark } \\
\text { Mathematics } \\
\text { Non-Affluent Schools } \\
\end{array}$ & $\begin{array}{c}\text { Advanced International } \\
\text { Benchmark } \\
\text { Science } \\
\text { Full sample } \\
\end{array}$ & $\begin{array}{c}\text { Advanced } \\
\text { International } \\
\text { Benchmark } \\
\text { Science } \\
\text { Non-Affluent Schools } \\
\end{array}$ \\
\hline $\begin{array}{c}\text { Adequacy of } \\
\text { teachers } \\
\text { with a } \\
\text { specialization in } \\
\text { science }\end{array}$ & & & $\begin{array}{l}0.036 \\
(0.112)\end{array}$ & $\begin{array}{l}0.054 \\
(0.132)\end{array}$ \\
\hline Adequacy & & & $0.290 * *$ & 0.087 \\
\hline $\begin{array}{l}\text { Of library materials } \\
\text { relevant to science } \\
\text { instruction }\end{array}$ & & & $(0.137)$ & $(0.167)$ \\
\hline $\begin{array}{l}\text { Audio visual } \\
\text { resources } \\
\text { for science } \\
\text { instruction }\end{array}$ & & & $\begin{array}{l}-0.075 \\
(0.119)\end{array}$ & $\begin{array}{l}0.255^{*} \\
(0.134)\end{array}$ \\
\hline $\begin{array}{l}\text { Adequacy of } \\
\text { computers } \\
\text { for science } \\
\text { instruction }\end{array}$ & & & $\begin{array}{l}0.018 \\
(0.165)\end{array}$ & $\begin{array}{l}0.030 \\
(0.208)\end{array}$ \\
\hline Adequacy of & & & 0.040 & -0.138 \\
\hline $\begin{array}{l}\text { Computer software } \\
\text { for science } \\
\text { instruction }\end{array}$ & & & $(0.145)$ & $(0.199)$ \\
\hline $\begin{array}{l}\text { Adequacy of } \\
\text { science } \\
\text { equipment and } \\
\text { material for science } \\
\text { instruction }\end{array}$ & & & $\begin{array}{l}-0.310^{*} \\
(0.158)\end{array}$ & $\begin{array}{l}-0.132 \\
(0.192)\end{array}$ \\
\hline Science laboratory & & & $\begin{array}{c}0.215^{* *} \\
(0.096)\end{array}$ & $\begin{array}{c}0.057 \\
(0.123)\end{array}$ \\
\hline $\begin{array}{l}\text { Not affected by } \\
\text { science } \\
\text { resource shortage }\end{array}$ & & & $\begin{array}{l}-0.214 \\
(0.217)\end{array}$ & $\begin{array}{c}0.277 \\
(0.337)\end{array}$ \\
\hline _cons & $\begin{array}{c}1.098 \\
(0.674)\end{array}$ & $\begin{array}{c}0.701 \\
(0.767)\end{array}$ & $\begin{array}{l}-1.222 * \\
(0.676)\end{array}$ & $\begin{array}{c}-1.762 * * \\
(0.850)\end{array}$ \\
\hline Obs. & 5102 & 4055 & 4600 & 3620 \\
\hline R-squared & 0.5439 & 0.4510 & 0.4868 & 0.3978 \\
\hline
\end{tabular}

Standard errors are in parenthesis

$* * * \mathrm{p}<0.01, * * \mathrm{p}<0.05, * \mathrm{p}<0.1$ 


\section{REFERENCES}

[1] Adams, C. (2010). Social determinants of student trust in high poverty elementary schools. Analyzing school contexts: Influences of principals and teachers in the service of students, 255-280.

[2] Araya, D., \& Peters, M. A. (Eds.). (2010). Education in the creative economy: Knowledge and learning in the age of innovation. Peter Lang.

[3] Badat, S. (2010). The challenges of transformation in higher education and training institutions in South Africa. Development Bank of Southern Africa, 8, 1-37.

[4] Botha, E. M. (2012). Turning the tide: creating Professional Learning Communities (PLC) to improve teaching practice and learning in South African public schools. Africa Education Review, 9(2), 395-411.

[5] Brian, K. (2015). OECD Insights Income Inequality the Gap between Rich and Poor: The Gap between Rich and Poor. OECD Publishing.

[6] Department of Basic Education (2019). Annual Performance Plan 2018/9. Pretoria: Department of Education.

[7] Fan, F. A. (2012). Class size: Effects on students' academic achievements and some remedial measures. Research in Education, 87(1), 95-98.

[8] Hanushek, E. A. (2012). The economic value of education and cognitive skills. In Handbook of education policy research (pp. 55-72). Routledge.

[9] Hungi, N. (2011). Accounting for variations in the quality of primary school education. SACMEQ, Southern and Eastern Africa Consortium for Monitoring Educational Quality.

[10] Mlachila, M. M., \& Moeletsi, T. (2019). Struggling to Make the Grade: A Review of the Causes and Consequences of the Weak Outcomes of South Africa's Education System. International Monetary Fund.

[11] Moloi, K. C., Dzvimbo, K. P., Potgieter, F. J., Wolhuter, C. C., \& van der Walt, J. L. (2010). Learners' perceptions as to what contributes to their school success: A case study. South

African Journal of Education, 30(3).

[12] Moses, E., van der Berg, S., \& Rich, K. (2017). A society divided: how unequal education quality limits social mobility in South Africa. Synthesis report for the Programme to Support Pro-Poor Policy Development (PSPPD). Stellenbosch.

[13] Mouton, N., Louw, G. P., \& Strydom, G. L. (2012). A historical analysis of the post-apartheid dispensation education in South Africa (1994-2011).

[14] Ndlovu, M. C. (2011). Re-envisioning the scholarship of engagement: Lessons from a university-school partnership project for mathematics and science teaching. South African Journal of Higher Education, 25(7), 1397-1415.

[15] Posel, D. (2011). Adult literacy rates in South Africa: A comparison of different measures. Language Matters, 42(1), 39-49.

[16] Sommer, M., \& Dumont, K. (2011). Psychosocial factors predicting academic performance of students at a historically disadvantaged university. South African Journal of Psychology, 41(3), 386-395.

[17] Soudien, C. (2016). South Africa: The struggle for social justice and citizenship in South African education. In The Palgrave International Handbook of Education for Citizenship and Social Justice (pp. 571-591). Palgrave Macmillan, London.

[18] Spaull, N. (2013). Poverty \& privilege: Primary school inequality in South Africa. International Journal of Educational Development, 33(5), 436-447.

[19] Spaull, N. (2013). South Africa's education crisis: The quality of education in South Africa 1994-2011. Johannesburg: Centre for Development and Enterprise, 1-65.

[20] Taylor, N., Mabogoane, T., \& Akoobhai, B. (2011). Service Delivery Research Project: The School Sector, report submitted to the Office of the Presidency, May. Johannesburg: JET Education Services.

[21] Wedekind, V. (2013). NSC pass requirements. A discussion document for Umalusi on the NSC pass mark. Pretoria: Umalusi.

[22] Wiberg, M. (2019). The relationship between TIMSS mathematics achievements, grades, and national test scores. Education Inquiry, 1-16. 